\title{
Struktur Kayu Tahan Gempa
}

\section{Oleh : Fachrurrozy}

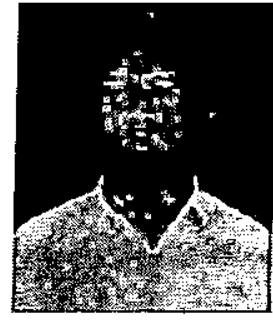

Ir.H.Fachrurozy, dilahirkandiYogyakartapadatanggal 29 Oktober 1943. S-1 diselesaikannya di Fakultas Teknik UGM tahun 1973 dan gelar S-2 diperoleh pada tahun 1976 di ITB. Dari tahun 1969 sampai sekarang menjadi dosentidaktetap FTSP Ulldisampingjabatannyasebagai dosentetap FTUGM sejaktahun 1974. Pemahmenjabat PD I Fak. Teknik Sipil UII tahun 1978 - 1984. Selain jabatan-jabatan struktural.yang dimilikinya, ia juga aktif dalam berbagai forum ilmiah \& profesi ditingkat Nasional maupun Internasional, salah satunya adalah " Conference on Structural Engineering" di Thailand pada tahun 1982.

\section{Pendahuluan}

Menurut Badan Meteorologi \& Geofisika, Wilayah Indonesia, khususnya Pulau Jawa dan Pantai Barat Pulau Sumatera, merupakan daerah Gempa I. Gempa bumi merupakan salah sätu dari gaya alam yang dapat menimbulkan kehancuran serta mendatangkan korban jiwa, korban harta benda, bahkan dapat mengganggu kestabilan kehidupan ekonomi, sosial, politik di daerah yang terkenabencana tersebut. Sampai sekarang gempa bumi tidak dapat dicegah dan belum diketahui dengan pasti serta belum dapat diramalkan secaratepatolehmanusia, kapan dan dimana akan térjadi gempa bumi dan sampai berapa besar kekuatannya. Adalah hak Allah SWT untuk menentukan, kapan dan dimana akan terjadi gempa bumi.

Apabila sebuah bangunan diamati, maka selama terjadinya gempa bumi, bangunantersebutakanmengalami gerakan vertikal dan gerakan horisontal. Gaya in- ertia atau gaya gempa, baik dalam arah vertikal maupun horisontal, akan timbul di titik-titik pada massa struktur. Dari kedua gaya ini, gaya dalam arah vertikal hanya sedikit mengubah gaya gravitasi yang bekerja pada śtruktur, sedangkan struktur pàda lazimnya direncanakan terhadap gaya vertikal dengan faktor keamanan (safety factor) yang memadai. Oleh karena itu, strukturpadaumumnya jarang sekali runtuh diakibatkan oleh gaya vertikal.

Sebaliknya, gaya horisontal yang diakibatkan gempa bumi menyerang titiktitik lemah pada struktur yang kekuatannya tidak memadai dan akan langsung menyebabkan kenuntuhan/kegagalan (failure). Dengan alasan inilah prinsip utama dalam peraincangan tahan gempa (earthquake-resiștant design) adalah meningkatkan kekuatan struktur terhadap gaya lateral (ke samping) yang pada umumnya tidak memadai.

Selarasdengangerakangempabumi 
horisontal dan vertikal, bangunan akan mengalami percepatan horisontal dan vertikal. Akibatnya diperolehkoefisien dan gaya gempa horisontal dan vertikal. Sedangkankoefisien dan gaya vertikal tidak berpengaruh besar dalam perançangan tahan gempa.

_Sebagai catatandapat dikemukakan, bahwa suatu bangunan walaupundirancang berdasarkan analisis tahan gempa, dapat mengalami kerusakan apabila memikul gaya gempa kuat yang tak terduga. Kerusakan ini diakibatkan oleh respons selama gempa bumi yang menimbulkan deformasi yang besar di atas batas elastis, atau deformasi inelastis, dengan deformasi yang menetapsetelah gempa bumi berakhir. Tingkat kerusakan yang timbul sangat bergantung pada deformasi residu (sisa). Pada kasus yang ekstrim, keruntuhan dapat terjadi, namun hal ini hanus dihindari. Dilihat dari sudut ekonomi, banguran tidak dapat diharapkan terus aman dan benaibenar tidak rusak oleh gempa bumi yang sangat kuat. Oleh karena itu, metode perancangan yang umumnya dapat diterima dewasa ini adalahmenerapkan tingkat daya tahan gempa yang logis.

\section{Kerusakan yang Ditimbulkan Akibat} Gempa Bumi.

Gempa bumi yang pernah terjadi dimuka bumi ini, sepanjang sejarah ummat manusia, telah menimbulkan korban jiwa. serta hartabenda yang amat besar diseluruh dunia. Apabila diperhatikan dengan seksama, suatu hal yang sangat kurang beruntung bahwa sebagian besar kérugian yang diakibatkan oleh gempa bumi justru diderita oleh negara-negara yang belum atau sedang berkembang. Sedangkan di negara yang sudah maju, kerusakan yang diakibatkan oleh gempa bumi relatif tak begitu besar. Bencana ini pada umumnya disebabkanoleh gagalnya bangunan buatan manusia.

Di negara-negara yang sudah maju, dengan teknik perencanaan serta pelaksanaan pembuatan bangunan yang semakin "sempuma", kerusakan-kerusakan yang diakibatkan oleh terjadinya gempa bumi dapat dikendalikan sekecil mungkin.

Apabila dilakukan pengamatan terhadap bangunan yang ada, khususnya bangunan untuktempat tinggal, maka dapat dikelompokkan menjadi 2 kategori, yaitu bangunan-bangunan engineered dan bangunan-bangunan non engineered. Nilai. perbandinganmasing-masingkategori agak berbedauntuknegara-negara maju, negaranegara sedang berkembang dan negaranegara belum berkembang. Sejarah telah mencatat, bahwa sebagian besar korban yang terjadi karena gempa bumi disebabkan oleh runtuhnya bangunan-bangunan non engineered.

Gempa bumi yang pemah terjadi di negara-negara Iran, Aljazair, serta Meksiko, telah mengakibatkan kerusakan yang amat besar, demikian juga gempa bumi yang pernah terjadi di Bali, Nusa Tenggara Barat, Tarutung, Lampung (Liwa) telah pula memporak porandakan bangunanbangunan hunian. Apabila dicermati kerusakan akibat dari gempa bumi tersebut, maka di Iran, Aljazair dan Meksiko lebih dari $70 \%$ bangunan yang rusak adalah dari bangunan yang terbuat dari tembok / pasangan dari tanah liat dengan kualitas yang masih sängat sederhana. Demikian pula akibat gempa yang terjadi di Bali, Nusa Tenggara Barat, Tarutung dan 
Lampung,kerusakantotal justru terjadi pada bangunan tembok dantanah liat, sedangkan bangunan yang memadai struktur kayu kurang begitu parah kerusakannya (masih dimungkinkan untuk diperbaiki kembali).

\section{Beberapa Kendala yang Dihadapi.}

Adalah suatu realita, bahwa di Indonesia sebagian besar rumah-rumah tinggal yang terdapat di kota-kota dan di pelosok-pelosok desa dibangun secara tradisional, dengankualitasbahan bangunan yang masih kurang memadai. Pada umumnya tipe bangunan disesuaikan dengan adat istiadat serta kebudayaan dan bahan-bahan bangunan setempat. Fakta menunjukkan bahwa bangunan-bangunan yang dibangun secara tradisional dengan memakai bahan konvensional seperti kayu, bambu serta material lokal lainnya dapat tahan terhadapkerusakan yang diakibatkan oleh gempa bumi.

Keadaan ekonomi yang membaik mengakibatkankecenderungan masyarakat untuk membangun rumah-rumah dengan dinding bata, karena mereka beranggapan bahwa rumah tembok akan meningkatkan status sosial bagi para pemiliknya. Keadaan ini sering tidak disertai dengan pemahaman pengetahuan "engineering" tentang bangunan.

Dalam PJPT II, kebutuhan akan perumahan sangat meningkat, akan tetapi sarana yang tersedia seperti keuangan, keahlian serta bahan bangunanmasih sangat terbatas. Hal ini akanmengakibatkanmutu/ kualitas rumah-rumah yang dibangun menjadi sangat rendah, jauh di bawah standart mutu rumah-rumah tradisional.

Daya tahan bangunan terhadap gempa-bumi yang sedang terjadi dipengaruhi oleh beberapa faktor :

1. Faktor perencanaan (hitungan struktur yang tepat \& benar)

2. Faktor jenis dan kondisi tanah tempat bangunan didirikan.

3: Faktor bahan bangunan yang dipakai (kayu, baja, beton bertulang, pasang bata).

4. Faktor pelaksanaan (memenuhi persyaratan teknis).

Dari ke empat faktor tersebut, yang paling dominan pengaruhnya adalah faktor perencanaan dan faktor pelaksanaan. Hal ini dapat dikemukakan, meskipun bahan bangunan yang dipakai dari bahan yang kualitasnya tinggi, namun perencanaan yang tidak tepat serta pelaksanaan tidak' memenuhi persyaratan teknis, akan menghasilkan bangunan yang rapuh daya tahannya terhadap gempa bumi.

Sebaliknya, meșkipun bahan bangunanyang dipakai kualitasnya rendah, namun perencanaan yang tidak tepat serta pelaksanaan tidak memenuhi persyaratan teknis, akan menghasilkan bangunan yang rapuh daya tahannya terhadap gempabumi.

Sebaliknya, meskipun bahan bangunan yang dipakai kualitasnya rendah, namun perencariaan tepat dan pelaksanaannya memenuhi persyaratan teknis, dapatmenghasilkan bangunan yang mempunyai daya tahan tinggi terhadap gempa bumi.

Apabila mutu bahan yang rendah ini disertai pula dengan penguasaan pengetahuan "engineering" yang miskin dalam perencanaannya, maka sudah dapat diramalkan bahwa bangunan-bangunan jenis ini (tembok) akan banyak mengalami kerusakan akibat gempa bumi. Kondisi seperti inilah yang menyebabkan banyak 
terjadi kerusakan padabangunan-bangunan (tembok) akibat gempa seperti yang telah di sebutkan di depan.

Kenyataan menunjukkan, bahwa sangatlah sulit untuk membendung kecenderungan membangun rumah/ bangunan semacam ini, ditambah pula dengan naiknya harga kayu terutama kayu jati yang merupakan idola bagi sebagian masyarakat Indonesia.

Letak geografis wilayah Indonesia termasuk salah satu daerah gempa bumi yang hebat di dunia (Daerah Gempa I). Namun sampai sekarang minatmasyarakat untuk mempelajari lebih dalam terhadap seluk belukgempabumi ini masih dirasakan sangat kurang.

Kecenderungan masyarakat untuk selalu meningkatkan status sosial mereka dengan berlomba-lomba membikin rumah tembok, ditambah dengan masih terlalu miskinnya akan pengetahuan "engineering" gempa yang dimilikinya, serta letak geografis wilayah Indonesia yang rawan terhadap gempa bumi, merupakan kendala utama bagi para pelaksana bangunan dalam usaha untuk menciptakan bangunanbangunan yang mempunyai daya tahan terhadap gempa bumi

\section{Menuju ke Suatu Struktur kayu Tahan Gempa.}

\section{Dasar Pemikiran}

Suatu struktur akan bergetar oleh adanya getaran gaya dinamis akibat gempa bumi, ledakan, angin, beban bergerak, mesin-mesin dan aliran air. Respons akibat hubungan antara gaya dinamis dan waktu dapat dikelompokkan dalam 2 jenis :

1. periodik (steady state)
2. transient

Getaran Gempa bumi adalah salah satu dari getaran yang menimbulkan respons transient.

\section{Jenis Deformasi}

Akibat getaran gaya dinamis, suatu struktur yang bergetar akan méngalami salah satu atau kombinasi dari 4 bentuk deformasi di bawah ini :

1. Deformasi ulur.

Suatu contoh dari deformasi ulur adalah getaran vertikal dari pondasi mesin.

2. Deformasi lentur

Terjadi pada struktur yang mempunyai massa terbagai rata sepanjang tinggi bangunan. Misalnya getaran dari cerobong dan free standing shear wall.

3. Deformasi geser

Pada umumnya terjadi pada getaran horizontal dari kolom-kolom bangunan bertingkat banyak yang disanggah dengan kolom-kolom lantai yang kaku.

4. Deformasi torsi

Terjadi akibat twisting dari bangunan yang mempunyai kekakuan yang berbeda sebagai suatu kesatuan.

Umumnya salah satu jenis deformasi akan dominan, meskipun seringkali kombinasi dari 2 jenis deformasi dapat terjadi. Sebagai misal seperti kombinasi deformasi geser dan lentur untuk mode tertinggi pada struktur cerobong dan kombinasi kolom dengan shear wall.

\section{Bahan Bangunan}

Seperti sudah dikemukakan di depan, bahwa salah satu faktor yang mempengaruhi daya tahan bangunan terhadap gempa bumi adalah faktor bahan bangunan yang dipakai. Banyak alternativ penggunaan bahan yang 
dipakai untuk bangunan. Setiap bahan bangunanmempunyai spesifikasi kekuátan yang tidak sama.

Pada dasamya pilihan atas suatu bahan bangunan tergantung dari sifat-sifat teknis, ekonomis, ketersediaan bahan serta keindahan bangunan.

Apabila dipilih sebagai bahan bangunan, maka perlulah diketahui sifatsifat kayu sepenuhnya, baik kekuatan, keawetan maupun kemudahan cara mengerjakannya. Untuk itu, para perencana maupun pelaksana perlu dibekali Ilmu Struktur Kayu yang memadai. Dalam era kemajuan teknologi seperti sekarang ini, hendaknya ditinggalkan cara berfikir tradisional dalam merencanakan bangunan serta cara melaksanakan bangunan yang masih banyak kurang memenuhi persyaratan teknis.

Di bawah ini disajikan kekuatan dari masing-masing bahan bangunan

Tabel 1 : Nilai modulus elastisitas (E)

\begin{tabular}{|c|c|c|}
\hline No & Bah a n & $\mathrm{E}\left(\mathrm{kg} / \mathrm{cm}^{2}\right)$ \\
\hline $\begin{array}{l}1 . \\
2 .\end{array}$ & $\begin{array}{l}\text { Baja } \\
\text { Beton dan beton bertulang } \\
\text { Kayu : sejajar serat } \\
\text { tegaklurus serat } \\
\text { Pasangan }\end{array}$ & $\begin{aligned} 2.100 .000 & \\
210.000 & \\
125.000 & (\mathrm{kl} . \mathrm{I}) \\
100.000 & (\mathrm{kl} . \mathrm{II}) \\
125.000 & (\mathrm{kl} . \mathrm{I}) \\
100.000 & (\mathrm{kl} . \mathrm{II}) \\
20.000 & \end{aligned}$ \\
\hline
\end{tabular}

Tabel 2 : Nilai tegangan berbagai macam bahan

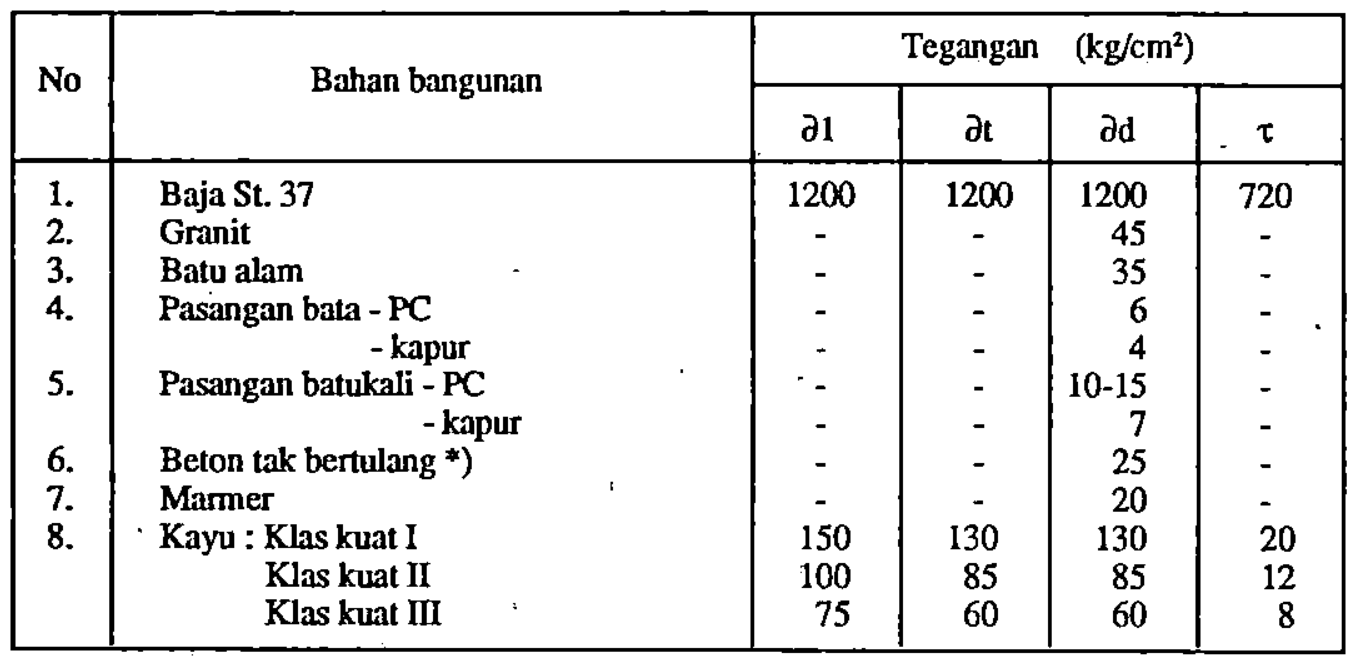

*) - Beton tak bertulang dengan campuran 1: $2: 3$ (bebas)

- Nilai tersebut tak berlaku utk K-175, K-225 dsb 


\section{Catatan :}

1. $\delta 1=$ tegangan lentur

$\delta \mathrm{t}=$ tegangan tarik

$\delta d=$ tegangan desak

$\tau=$ tegangan geser

2. Untuk bahan granit, batu alam, pasangan bata/batu, beton tanpa tulangan dan marmer tidak diperhitungan tegangan tariknya.

Dari tabel 1 dan tabel 2 terlihat, bahwa nilai modulus elastisitas kayau dan tegangan-tegangan kayu, mempunyai nilai jauh lebih tinggi dibandingkan dengan bahan-bahan yanglain (kecuali baja). Dapat disimpulkan bahwa bahan kayu relatiflebih kuat daya tahannya dibanding bahan lain selain baja. Hal ini merupakan faktor nilai lebih dari bahan kayu.

Selain mempunyai tegangan tarik yanglebih tinggi, bahan kayu masih mampu untuk melawan deformasi ulur (tarik), lentur, geser maupun torsi karena memang memiliki tegangan-tegangan untuk melawan itu, sedangkan pasangan bata dan sejenisnya tidak mempunyai kemampuan melawan deformasi -deformasi tersebut.

\section{Perencanaan}

Faktor perencanaan teknis suatu bangunan, akan memegang peranan yang amat penting demi terwujudnya suatu bangunan yang strukturnya dapat dipertanggung jawabkan terhadap bebanbeban yang bekerja. Apabila suatu bangunan diperhitungkan menerima gayagaya akibat gempa bumi, dan perencanaan teknisnya memenuhi persyaratan untuk itu, insya Allah bangunan tersebut mampu menahan gaya-gaya gempa yang diperhitungkan tersebut. Namun demikian apabila temyata bahwa gaya-gaya gempa yang direncanakan itu jauh melampaui perkiraan yang ditetapkan, tentunya kerusakan konstruksi tidak pula dapat dihindari.

Dalam era kemajuan tekonologi seperti sekarang ini, hendaknya para pelaksana bangunan meninggalkan cara berfikir "tradisional" dalam merencanakan serta melaksanakan suatu bangunan, agar dapat dikurangi semaksimal mungkin terjadinyakerusakan struktur akibat gempa bumi.

Untuk bangunan-bangunan yang tinggi (high rise building) dengan struktur beton bertulang atau baja, para pakar bangunan sudah merencanakannyadengan Dasar-dasar Perhitungan Bangunan Tahan Gempa. Akan tetapi, untuk bangunanbangunan rumah tinggal yang tingginya kurang dari 10 meter, faktor pengaruh gempa bumi pada umumnya masih belum diperhitungkan. Dengan demikian antisipasi terhadap kerusakan akibat gempa bumi belum dilakukan.

Dengan memakai bahan kayu yang relatif lebih tahan terhadap gaya-gaya tarik,tekan, lentur dan geser yang bekerja, dibanding dengan bahan pasangan bata dan beton tidak bertulang, maka sebetulnya secara tidak langsung antisipasi terhadap kerusakan akibat gempa bumi tersebut sudah dilakukan.

Berbicara mengenai struktur kayu yang dipakai untuk bangunan-bangunan sipil, ada 3 hal pokok yang perlu mendapatkan perhatian:

1. Memilih jenis kayu yang klas kuatnya tinggi serta mempunyai keawetan yang . tinggi.

2. Merencanakan dimensi batang yang 
memenuhi persyaratan.

3. Merencanakan secara benarsambungansambungan yang akan dibuat didasarkan atas gaya-gaya yang terjadi.

Sambungan-sambungan yang dimaksud dapat berupa sambungan perpanjangan (karena panjang kayu terbatas), dan juga sambungan pertemuan antara batang satu dengan batang lainnya dalam arah yang tidak satu sumbu.

Dari 3 hal tersebut, pokok permasalahan yang perlu mendapatkan perhatian para pakar bangunan adalah di tempat sambungan yang akan dibuat tersebut.

Baik perencanaan dimensi batang maupun perencanaan sambungan, harus memenuhi ketentuan perhitungan serta persyaratan yang telah ditetapkan oleh Peraturan Konstruksi kayu Indonesia (PKKI). Kenyataannya dalam praktek masih sering di jumpai sambungan yang tidak memenuhi persyaratan, baik bentuknya maupun pemakaian alat sambung yang kurang memenuhi syarat.

Sebagai contoh dapat dikemukakan kesalahantersebutadalah:sambungan yang seharusnya menahan lentur, dilaksanakan dengan menggunakan bentuk sambungan yang menahan gaya tarik, atau sambungan yang seharusnya menahan gaya tarik, dilaksanakan dengan bentuk sambungan yangmenahan gaya tekan. Sambungan yang tidak tepat semacan ini banyak sekali di jumpai pada bangunan. rumah tinggal sederhana bahkan juga rumah tinggal mewah, yang pelaksanaannya tidak didasari dengan Ilmu Struktur Kayu. 'Apabila temyata terjadi lentur tambahan atau gaya tarik akibat gempa bumi, dapat dipastikan bahwa sambungan yang salah tersebut akan mengalami kehancuran/kegagalan struktur.

Adalah suatu kenyataan bahwa didalam Peraturan Konstruksi Kayu Indonesia ( PKKI ), penetapan tegangantegangan kayu, baik untuk tcgangan lentur, tegangan tarik, tegangan tekan serta tegangan' geser,telah mempunyai angka keamanan yang tinggi. Hal inipun juga ikut "menjamin" bahwa penggunaan struktur kayu untuk bangunan lebih tahan terhadap kerusakan akibat gempa bumi.

\section{Faktor Jenis dan Kondisi Tanah}

Suatu kenyataan yang tidak dapat dipungkiri, bahwa semua bangunan sipil, khususnya bangunan tempat tinggal pasti terletak di atas tanah. Diatas tanah inilah dibangun fondasi, yang merupakan tumpuan untuk bangunan-bangunan di atasnya. Fondasi akan sangat memegang peranan penting dalam menjaga kestabilan bangunan tersebut. Artinya, apabila dalam menentukan janis dan ukuran fondasi tidak tepat, akan terjadi kegagalan struktur fondasinya, sehingga akan mengakibatkan deformasi pada bagian-bagian di atas fondasi.

Bentukserta ukurandari fondasi yang direncanakan akan dipengaruhi oleh jenis serta kondisi tanah setempat. Setiap jenis tanah akan mempengaruhi besarnya koefisien tanah (kt) yang dalam perencanaan bangunan tahan gempa merupakan suatu faktor yang harus dimasukkan. Disamping itu, besarnya koefisien tanah juga dipengaruhi jenis strukturyang dipakai pada bangunan tersebut. Tabel di bawah ini menunjukkan pengaruh-pengaruh tersebut. 
Tabel 3 : Koefisien tanah untuk berbagai jenis tanah dan jenis struktur

\begin{tabular}{|l|l|c|c|c|c|}
\hline \multicolumn{2}{|c|}{ T a n a h } & \multicolumn{4}{c|}{ Nilai kt untuk jenis struktur } \\
\hline Jenis & $\begin{array}{c}\text { Daya du- } \\
\text { kung } \\
\left(\mathrm{kg} / \mathrm{cm}^{2}\right)\end{array}$ & Baja & $\begin{array}{c}\text { Bt. ber- } \\
\text { tulang }\end{array}$ & Kayu & $\begin{array}{c}\text { Pasa- } \\
\text { ngan }\end{array}$ \\
\hline Keras & $>5$ & 0,6 & 0,8 & 0,6 & 1,0 \\
Sedang & $2-5$ & 0,8 & 0,9 & 0,8 & 1,0 \\
Lunak & $0,5-2$ & 1,0 & 1,0 & 1,0, & 1,0 \\
Amat Lunak & $0-0,5$ & 1,0 & 1,0 & 1,0 & 1,0 \\
\hline
\end{tabular}

Sumber : Imam Subarkah, Ir. 1984, Vademekum Lengkap Tek. Sipil

Tampak pada tabel,bahwa untuk jenis struktur kayu dan struktur baja mempunyai koefisien tanah $(\mathrm{kt})$ yang lebih kecil dibanding denganjenis struktur beton maupunpasangan. Ini menunjukkan bahwa daya tahan terhadap gempa bumi pada struktur kayu dan baja lebih tinggi dibandingkan dengan jenis pasangan. Perlu diingat bahwa kocfisien tanah ini akan menentukan pula besamya koefisien gempa yang diperhitungkan.

Dapat disimpulkan disini bahwa peran faktor jenis scrta kondisi tanah dalam kestabilan suatu bangunan, baik yang diakibatkan oleh beban-beban rencana maupun beban-beban akibat gempa bumi amatlah penting. sertatidak dapat diabaikan begitu saja.

\section{Pelaksanaan}

Faktor yag tidak kailah pentingnya dalam menciptakan suatu bangunan yang tahan gempa bumi adalah faktor pelaksanaan. suatu bangunan, yang meskipun sudah direncanakan secara benar berdasarkan beban/gaya-gaya rencana, namun apabila dalam pelaksanaannya menyimpang dari ketentuan-ketentuan teknis, baik pengurangan kuantitas maupun penurunan kualitas bahan, akan menghasilkan suatu bangunan yang secara teknis diragukan kekuatannya. Untuk bangunan-bangunan yang dapat diharapkan tahan gempa bumi, hal ini akan diperparah lagi apabila dalam perencanaannya tidak pula diperhitungkan gaya-gayagempa yang mungkin terjadi.

Untuk menunjang agar pelaksanaan dapat dijalankan secara baik dan benar, maka diperlukan adanya pengawas pelaksanaan. Namun disayangkan bahwa dalam praktek sampai saat ini, para pengawas pelaksaaan biasanya hanya "tertarik" mengawasi bagian-bagian pekerjaan yang biasanya mereka anggap "penting" saja, misalnya pada bagian pekerjaan beton saja, sehingga bagian lain seperti bagian pekerjaan kayu dan semacamnya, luput dari pengawasan mereka. Bagian tersebut cukup mercka serahkan kepada tukang, karena dianggap tidak penting. Oleh sebab itu, terjadinya penyimpangan pada pekerjaan kayu (membuat sambungan yang tidak tepat dan kurang memenuhi syarat), amat seringkali terjadi khususnya pada bangunan-bangunan 
rumah tinggal.

Agar dapat dihasilkan struktur kayu yang tahap terhadap gempa bumi, perencanaan struktur kayu harus direncakan dengan benar dan memenuhi peraturan. Untukmencegah terjadinya penyimpangan pelaksanaan, dibawah ini dikemukakan beberapa hal penting yang harus mendapatkan perhatian pengawas pelaksanaan, yaitu :

1. Hubungan fondasi dengan sloof kayu

2. Hubungan sloof kayu dengan kolomkolom kayu

3. Hubungan dinding ring balk kayu dengan kolom-kolom kayu pengaku dinding.
4. Hubungan rangka kayu dengan dinding papan kayu / dinding tembok

5. Hubungan kuda-kuda dengan dinding atau kolom kayu

6. Ikatan memanjang vertikal antar kudakuda

7. Hubungan antara kuda-kuda dengan balok bubungan

8. Sambungan-sambungan kayu (sambungan lentur, sambungan tarik dan sambungan tekan)

Gambar-gambar dibawah ini memperlihatkan hubungan-huungan tersebut, dan ditekankan untuk dapat dilaksanakan dengan benar.

Gambar 1. Hubungan fondasi dengansloof kayu
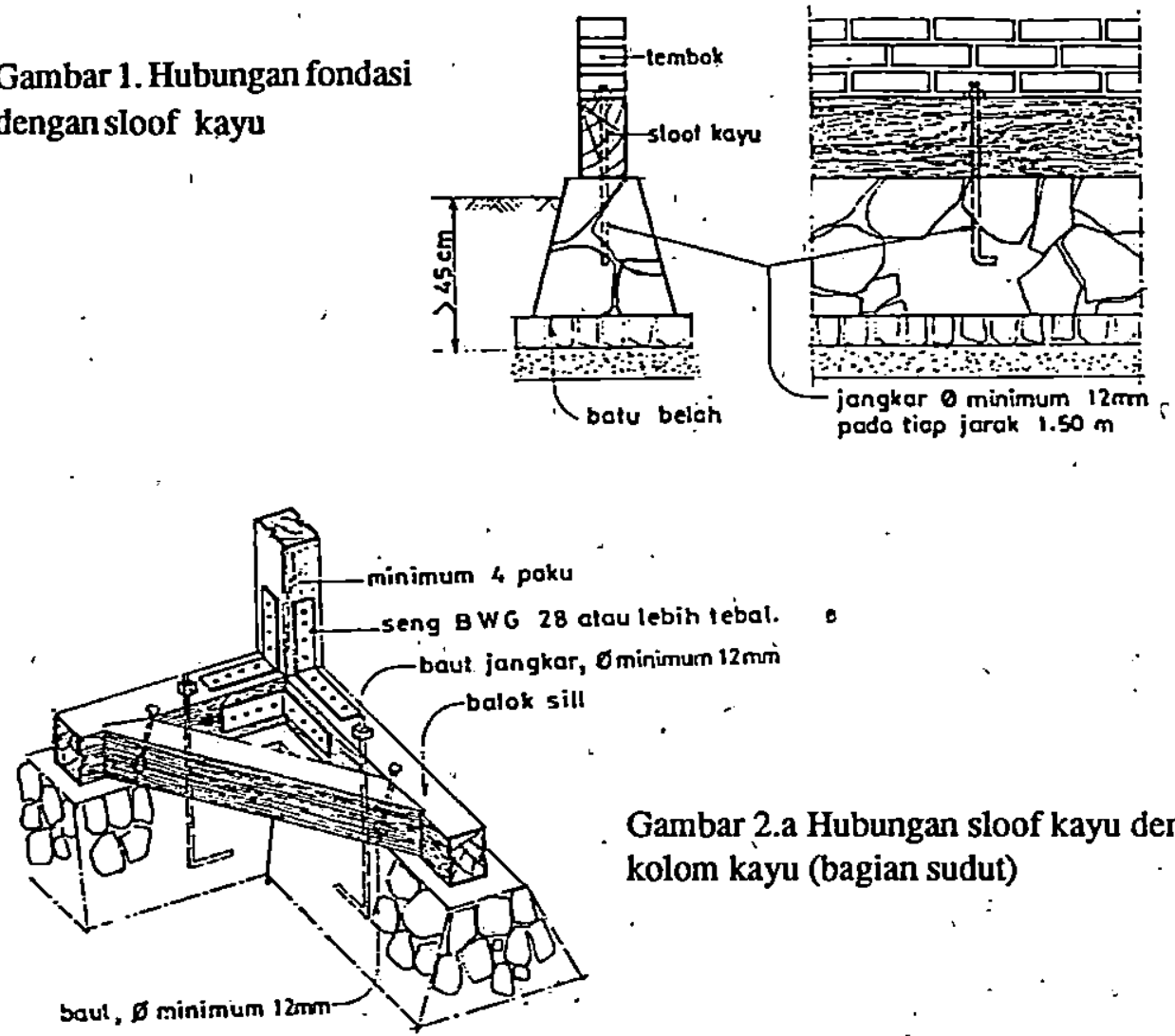

Gambar 2.a Hubungan sloof kayu dengan kolom kayu (bagian sudut) 

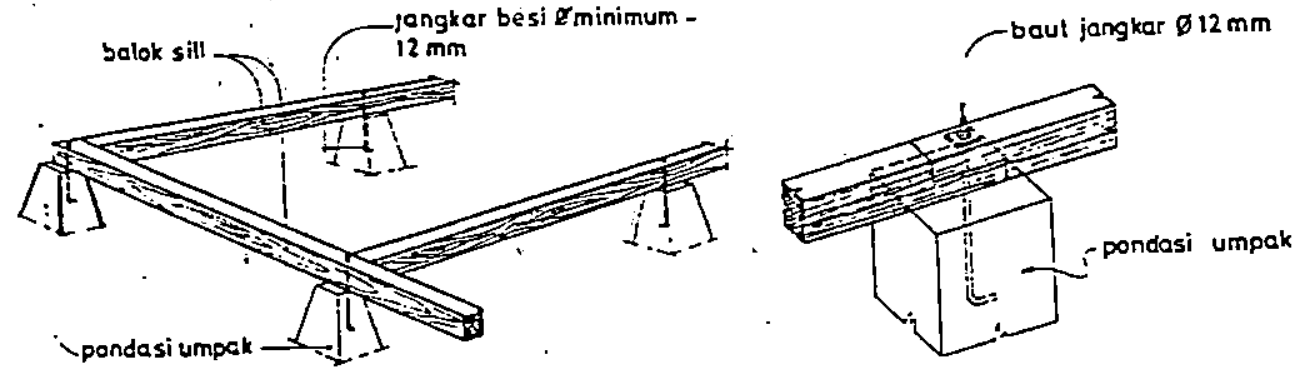

DETAIL HUBUNGAN

Gambar 2.b. Hubungan sloff kayu dengan fondasi umpak

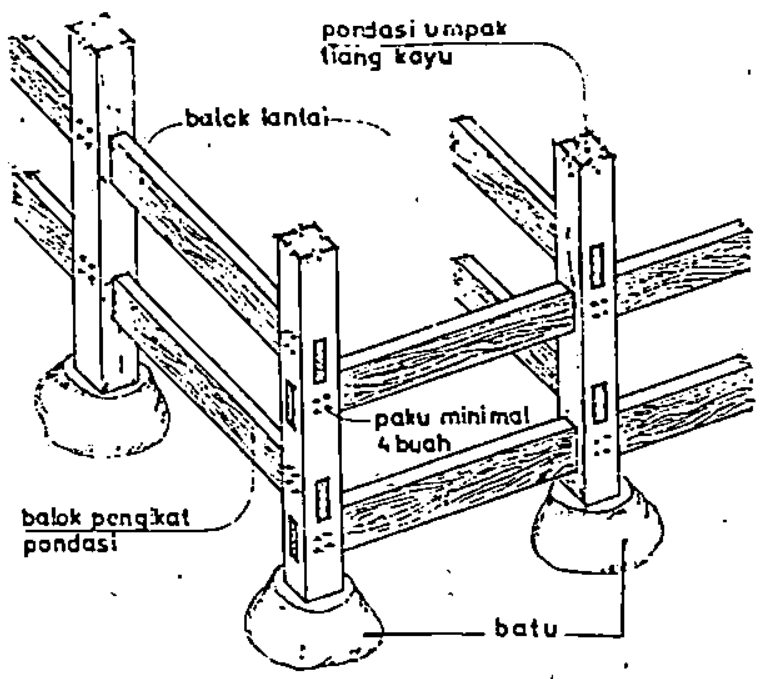

Gambar 2.c. Hubungan fondasi umpak/batu dengan tiang kayu

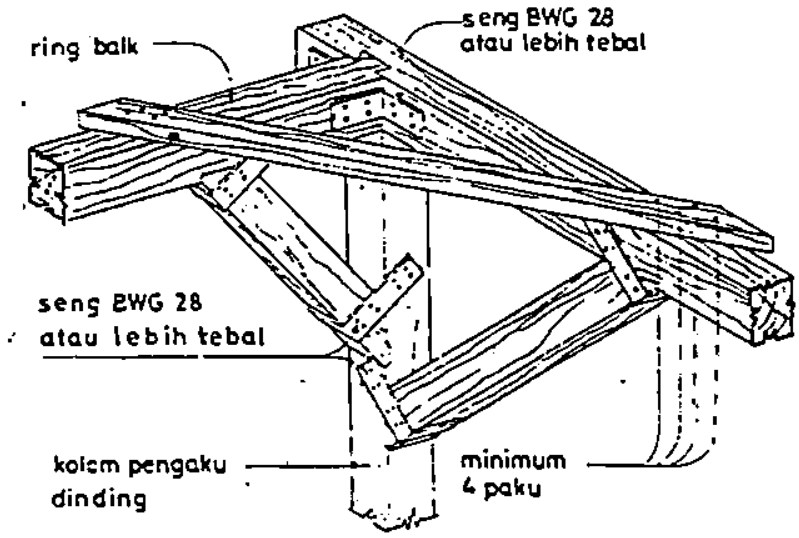

Gambar 3. hubungan ring balk kayu dengan kolom 


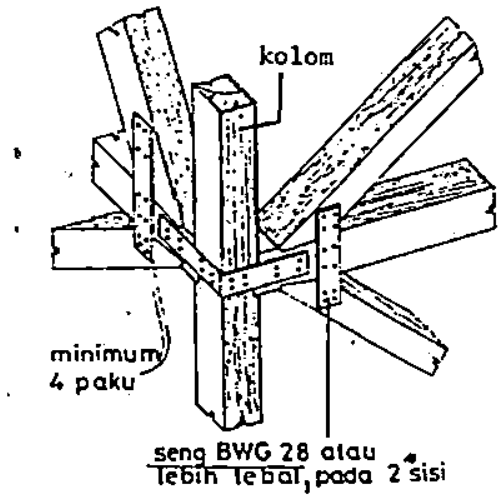

Gambar 4 Hubungan kolom dengan balokbalok rangka

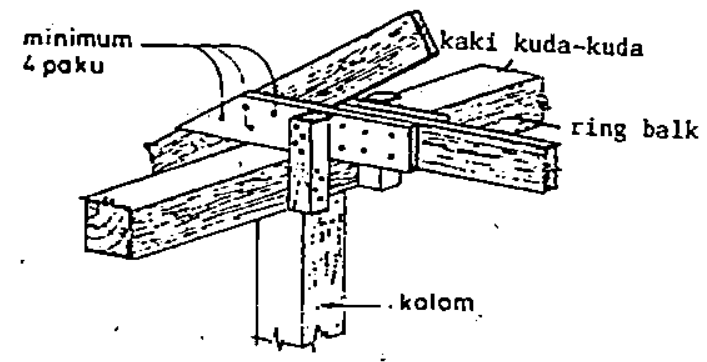

Gambar 5. Hubungan kuda-kuda dengan kolom kayu/ring balk

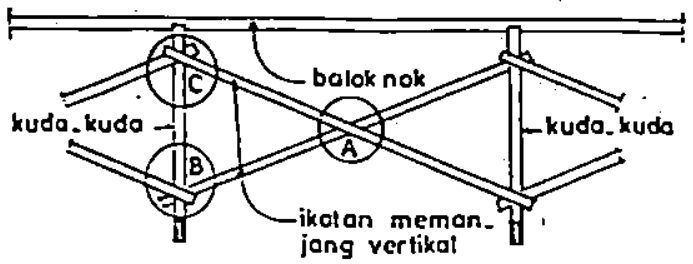

Gambar6. Ikatan memanjang vertikal antar kuda-kuda

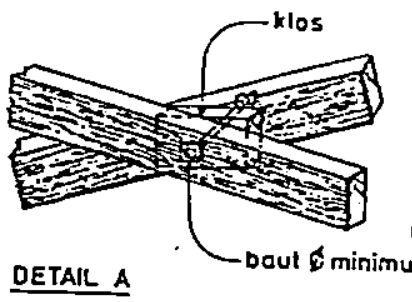

Gambar 6.a. Detail sambungan ikatan
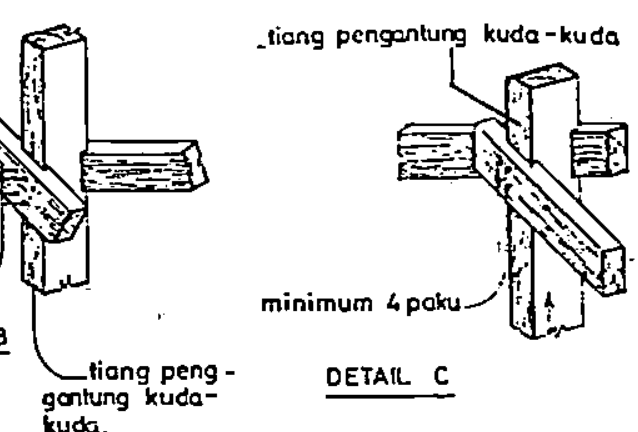

Detall C

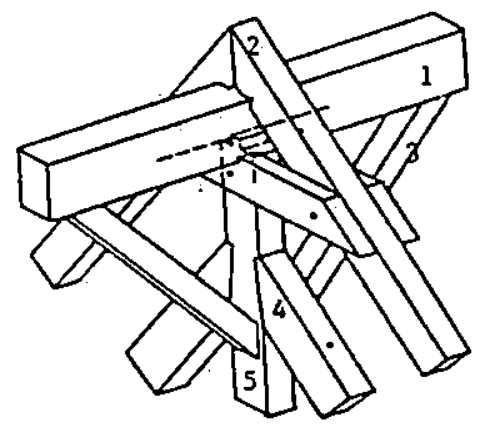

1. Balok bubungan

2. Usuk (kasau)

3. Peyokong

4. Kaki kuda-kuda

5. Penggantung

Gambar 7. Hubungan antar kuda-kuda dengan balok bubungan 

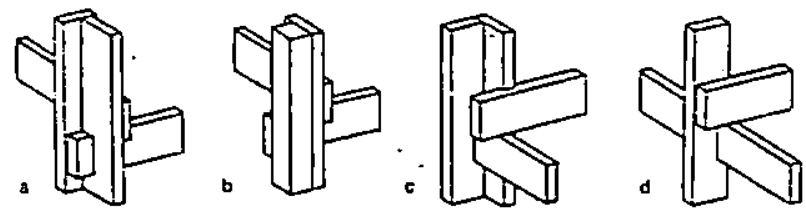

Gambar 8. Beberapa contoh sambungan kayu

\section{Kesimpulan dan Saran}

1. Adanya kecenderungan sebagian masyarakat untuk berpacu dalam meningkatkan status sosial mereka dengan cara membuat bangunan rumah tinggal dari pasangan tembok, tanpa diikuti dengan pemakaian teknologi yang tepat.

2. Ditinjau dari segi ekonomi, bangunan tidak dapat diharapkan terus menerus aman dan benar-benar tidak rusak oleh gempa bumi yang sangat kuat, namun perancangannya harus dapat diterima dengan menetapkan tingkat daya tahan gempa yang logis.

3. Untuk mengurangi tingkat kerusakan bangunan terhadap gempa bumi, dapat dilakukan dengan cara :

- Memakai bahan struktur yang mempunyai daya tahan tinggi terhadap semua gaya-gaya yang mungkin terjadi akibat gempa bumi.

- Menetapkan dalam perencanaannya faktorgempa sesuai dengan persyaratan yang telah ditetapkan.

4. Bahan kayu secara alamiah mempunyai daya tahan terhadap gempa bumi, karena didalam bahan kayu ternyata mempunyai tegangan -tegangan dalam arah lentur, tekan, tarik dan geser.

5. Fungsi pengawasan dalam pelaksanaan pekerjaan strukturbangunan harus lebih ditingkatkan lagi, tidak hanya pengawasan dalam pekerjaan-pekerjaan tertentu saja, akan tetapi juga meliputi pengawasan pada pekerjaan yang mungkin dianggap "remeh", namun mempunyai peran yang menentukan dalam kestabilan struktur bangunan tersebut. Misalnya pada bagian-bagian titik lemah dari suatu struktur (periksa gambar-gambar di depan)

\section{Penutup}

Tulisan yang disajikan secara sederhana ini, penulis rasa masih sangat jauh dari memuaskan. Namun penulis berharap, agar masyarakat menjadi lebih mempunyai wawasan, terutama mengenai sebab dan akibat yang dapat ditimbulkan oleh adanya gempa bumi.

Kepada masyarakat dihimbau agar dalam melaksanakan pekerjaan bangunan haruslah peduli akan hal-hal yang mungkin dianggap remeh namun sebenamyapenting. untuk mendapatkan perhatian.

semoga tulisan ini dapat membawa manfaat bagi para pembaca.

\section{Daftar Pustaka}

Fachrurrozy, Ir, 1980, Bahan kayu Untuk bangunan-bangunan Teknik Sipil, Fakultas teknik, Universitas Islam Indonesia, Yogyakarta: 
Heinz Frick, Ir, 1982, Ilmu Konstruksi Suwarno Wiryomartono, Ir, 1987, Bangunan Kayu, Yayasan Konstruksi Kayu, Fakultas Kanisius, Yogyakarta. Teknik UGM, Yogyakarta.

Iman Subarkah, Ir, 1984, Vademekum Teddy Boen, Ir \& Wendy T, Ir, 1977, Lengkap Teknik Sipil, Idea Dasar-dasar Perhitungan Dharma, Jakarta.

Kiyoshi Muto, 1987, Analisis Perancangan bangunan Tahan Gempa, Jakarta

Gedung Tahan Gempa, alih Teddy Boen, Ir, 1978, Manual Bangunan bahasa oleh Wira MSCE, Erlangga, Jakarta Tahan Gempa (rumah tinggal), Jakarta. 